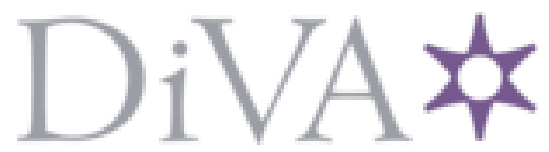

http://www.diva-portal.org

\title{
Postprint
}

This is the accepted version of a paper published in The Anthropocene Review. This paper has been peer-reviewed but does not include the final publisher proof-corrections or journal pagination.

Citation for the original published paper (version of record):

Kunnas, J. (2017)

Storytelling: From the early Anthropocene to the good or the bad Anthropocene.

The Anthropocene Review, 4(2): 136-150

https://doi.org/10.1177/2053019617725538

Access to the published version may require subscription.

N.B. When citing this work, cite the original published paper.

Kunnas, Storytelling: From the early Anthropocene to the good or the bad Anthropocene, The Anthropocene Review (Volume: 4 issue: 2) pp. 136-150. Copyright (C 2017 The Author(s). Reprinted by permission of SAGE Publications.

Permanent link to this version:

http://urn.kb.se/resolve?urn=urn:nbn:se:kth:diva-211910 
Jan Kunnas, "Storytelling: From the early Anthropocene to the good or the bad Anthropocene,” The Anthropocene Review, 2017, Vol 4, Issue 2, pp. 136 - 150. http://journals.sagepub.com/doi/full/10.1177/2053019617725538

Copyright @ 2017 (Copyright Holder). Reprinted by permission of SAGE Publications.

\section{Storytelling: From the Early Anthropocene to the Good or the Bad}

\section{Anthropocene}

\section{Introduction}

Crutzen and Stoermer (2000) suggest that humans have become a geological force on their own, and Earth had thus left the Holocene and entered a new geological epoch, the Anthropocene. Accordingly, August 29, 2016, the Working Group on the 'Anthropocene' (2016) recommended to the International Geological Congress that "Humanity's impact on the Earth is now so profound that a new geological epoch - the Anthropocene - needs to be declared”. Evidence of the new epoch included that human activity had pushed extinction rates of animals and plants far above the long-term average, increased levels of carbon dioxide in the atmosphere at the fastest rate for 66 million years, produces 500 million tons of plastics a year leaving identifiable sediments for future generations to discover, doubled the nitrogen and phosphorous in our soils in the past century, and left a permanent layer of airborne particulates in sediment and glacial ice (Waters et al., 2016; Carrington, 2016). 
The Anthropocene is a powerful concept, both as a pedagogical tool and as guidance for research and policy. It challenges conventional understandings of culture, society and nature as self-contained ontological domains (Chernilo, 2016). As Colebrook (2016: 82) states: "The Anthropocene is not only a geological declaration, but a series of diagnoses that generate imperatives.” Taylor and Pacini-Ketchabaw (2015: 507) argue that the "naming of the Anthropocene is a moment of pedagogical opportunity in which we might decentre the human as the sole learning subject and explore the possibilities of interspecies learning”. Regarding research, a similar decentering would, for example, have major implications for philosopher Rawls’ (1999) Theory of justice, which has already been re-interpreted due to climate change, as it would require a reassessment of who are the least advantaged (Barnett and Adger, 2003; Kunnas, 2012). According to Paglia (2015), in history the Anthropocene entails a collapse of natural history and human history into something that Latour (2014) calls geostory, echoing Chakkrabarty (2009). On the other hand, Crist (2013: 129) argues that:

The Anthropocene has morphed into a discourse that is organizing the perception of a world picture (past, present, and future) through a set of ideas and prescriptions that is tenaciously anthropocentric; indeed, the championed name itself-Anthropocene, or the age of Man—evokes the human-centeredness that is at the root of our ecological predicament. 
The focus in this paper is on storytelling, joining the footsteps of Bonneuil (2015) arguing that "Stories matter for the Earth". I will examine, whether the Anthropocene concept, can be used as “a broad metaphor to motivate holistic understandings of human impacts on the Earth System” (Bowman, 2015: 73; see also Chin et al., 2013). I will show how a multi-stage Anthropocene suggested by Ruddiman (2013) and Glikson (2013) could solve the human-centeredness of the concept, and most importantly unleash the power of storytelling by presenting a multifaceted picture of human agency in the Anthropocene. Thus also evade fatalistic thinking that the trajectory of current industrial-consumer civilization might evoke (Barje, 2015; Crist, 2007; Meyer 2006).

\section{Stages of the Anthropocene}

While the term itself has achieved large acceptance, the Anthropocene has no agreed start date. On contrary several competing timings have been suggested for when the Earth left the interglacial state called the Holocene, and entered the Anthropocene. Some of its proponents argue that we have recently entered the Anthropocene, and others might time its start thousands of years into the past. Crutzen (2002) himself suggested that this new geological epoch may have begun at the time of the Industrial Revolution with large-scale burning of coal. He, however, stated that alternative proposals can be made. Proposals has indeed been made, so many that we are below 
only able to list a few exemplifying the large discrepancy in the timing of the Anthropocene. In fact, according to Angus (2015), “a dozen or more proposals for dating the Anthropocene have been made to the” above mentioned Working Group on the 'Anthropocene', created to investigate whether to formally define the Anthropocene as a geological epoch.

To formally declare the Anthropocene as a geological epoch, scientists first have to identify and define a boundary line, or marker. The currently strongest candidate is the distinctive radioactive signature left by atom bomb tests. This would time the start of the Anthropocene as late as for the Trinity test on July 16, 1945. Thus the start of the Anthropocene would more or less coincide with the post-1950 acceleration of the human imprint on the Earth System, the Great Acceleration, suggested by Zalasiewicz et al. (2014) and Steffen et al. (2015a) as the start of the Anthropocene.

But, not even the Working Group on the 'Anthropocene' (2016) is unanimous in this sense, although in their vote the majority favored 1950, which received 28.3 votes, but around 3000 years ago received 1.3 votes, 1964 received 1.3 votes and diachronous 4 votes. Clearly, some member of the working group even split his/her own vote. Similarly, plutonium fallout received 10 votes, radiocarbon bomb spike 4, carbon dioxide concentration 3, plastic 3, fuel ash particles: 2, carbon isotope change 2 and lead, persistent organic pollutants and technofossils 1 vote each as the primary signal, while 2 were uncertain and 6 abstained. Besides dividing the working group and the 
research community, this large discrepancy also has major implications regarding humans' role in Changing the Face of the Earth as I will show later on (cf. Thomas 1956).

Ruddiman et al. (2015: 39) argues, that: "Selecting 1945 as the start of the ‘Anthropocene' would implicitly omit... ...extensive agricultural and early-industrial alterations.” They ask whether “...it really make sense to define the start of a humandominated era millennia after most forests in arable regions had been cut for agriculture, most rice paddies had been irrigated, and $\mathrm{CO}_{2}$ and $\mathrm{CH}_{4}$ concentrations had been rising because of agricultural and industrial emissions?”

Ruddiman (2003 and 2005) himself argues that the Anthropocene started already when humans commenced large-scale agriculture in various parts of the world $5000-8000$ years ago. According to Ruddiman (2005: 105), without the release of $\mathrm{CO}_{2}$ and methane from these activities the "Earth should have undergone a large natural cooling during the last several thousand years, and that at least a small glaciation would have begun several millennia ago...” In other words the Holocene or at least the continuation of its goldilocks climatic conditions is due to human activities. Williams et al. (2015) suggest an even earlier date to this so called early Anthropocene hypothesis. Looking at human impacts on the biosphere, they argue that Anthropocene started to emerge around 2.6 million years ago with the development of tool use in Africa, and accelerated around 
14000 years ago with the domestication of animals. The first one is perhaps quite over the top considering that modern humans, "wise man" (Homo sapiens), only evolved within the last 200000 years.

Based on his so called early Anthropocene hypothesis Ruddiman (2013: 65) argues that “defining 1850 [AD, or any later time] as the start of the Anthropocene does not make sense, despite the marked acceleration of many anthropogenic effects after that time.” Instead, he suggests a two-phase Anthropocene with an early phase dating back thousands of years and a contemporary phase marked by the explosion of anthropogenic impacts starting with the Industrial Revolution (Ruddiman, 2013; Braje, 2015). Comparably, Glikson (2013) has proposed a three-staged model: 1) early Anthropocene since our hominid ancestors learned to control fire from at least $>1.8$ million years ago; 2) mid Anthropocene since the commencement of Neolithic agriculture around 5000 years ago; 3) and late Anthropocene since the Industrial Revolution. These suggestions have, however, been rejected by the Working Group on the 'Anthropocene' for not conforming to the appropriate stratigraphic criteria for formalization.

My interest is, however, not in the formalization of the Anthropocene concept. I will, however, argue that splitting the Anthropocene into several consecutive stages as suggested by Ruddiman (2013) and Glikson (2013) would be helpful for a holistic understanding of human impacts on the Earth. Compared to Glikson's (2013) three 
staged model, I would though add a fourth stage and suggest somewhat different earlier stages. Thus my suggestion for a four staged Anthropocene would be the following one:

1) The early Anthropocene, which began 5000-14 000 years ago depending on whether we time it according to the domestication of animals or the beginning of large-scale agriculture. This would also include the Greek and Roman civilizations, and other early civilizations.

2) The first acceleration phase of the Anthropocene beginning with large-scale burning of coal at the time of the Industrial Revolution.

3) The post-1950 Great Acceleration.

4) And finally the good or the bad Anthropocene depending on whether humans take decisive action in time that ensures us staying within the planetary boundaries providing a safe operating space for humanity. ${ }^{1}$

\section{The Good Anthropocene}

The Anthropocene does not get good by simply declaring it good (cf. Asafu-Adjaye et al., 2015). We need on contrary clear definitions of what makes the Anthropocene good. This would also provide clear signals on the direction we are moving in. As a measure

\footnotetext{
${ }^{1}$ Simon Dalby (2016) argues that the Anthropocene is neither good nor bad. He is right in the sense that the Anthropocene is not an actor doing good or bad decisions; it is up to us ourselves whether the Anthropocene turns out good or bad.
} 
of when we might enter the good Anthropocene, I suggest it will occur if and when humans make decisive action to return within the planetary boundaries "based on the intrinsic biophysical processes that regulate the stability of the Earth System” (Steffen et al. 2015b). In other words when humans are not only a geological force on its own, but are also in control of the consequences of their actions. The planetary boundary framework proposed by Rockström et al. (2009) was designed to define a "safe operating space for humanity”. They identified key Earth System processes where human perturbation is having global-scale systemic consequences and their boundary levels that should not be transgressed if we are to avoid unacceptable global environmental change.

Steffen et al. (2015b) estimated recently, that four out of nine planetary boundaries have already been overstepped as a result of human activity: 1) climate change, 2) loss of biosphere integrity, 3) land-system change, and 4) altered biogeochemical cycles (phosphorus and nitrogen). I suggest that, we will be in the good Anthropocene, when we have returned within these boundaries or at earliest when we are on a trajectory taking us back within these boundaries.

In 2015, the planetary boundaries framework was updated to account for scientific advances over the past five years (Steffen et al., 2015b). Regarding climate change the control variables and boundaries originally proposed were retained, but the zone of 
uncertainty for the Carbon dioxide control variable was narrowed from 350-550 ppm to 350-450 ppm $\mathrm{CO}_{2}$. The boundaries for ocean acidification and stratospheric ozone were retained on the originally proposed levels (mean surface seawater saturation state with respect to aragonite $\geq 80 \%$ of pre-industrial levels and $<5 \%$ reduction in ozone concentration from pre-industrial level of 290 Dobson Units). The original global-level boundary for phosphorus (annual P inflow to oceans not to exceed 10 times its natural background weathering), based on the prevention of large-scale oxygen depletion in oceans, was retained, and supplemented with a regional-level phosphorus boundary, designed to avert widespread eutrophication of freshwater systems, at a flow of $6.2 \mathrm{Tg} \mathrm{P}$ per year from fertilizers (Carpenter and Bennett, 2011). The nitrogen boundary was taken from the comprehensive analysis of De Vries et al. (2013), which proposed a boundary for eutrophication of aquatic ecosystems of $62 \mathrm{Tg} N$ per year from industrial and intentional biological $\mathrm{N}$ fixation.

The global freshwater use boundary was retained complemented "with a basin-scale boundary for the maximum rate of blue water withdrawal along rivers, based on the amount of water required in the river system to avoid regime shifts in the functioning of flow-dependent ecosystems.” The control variable for land-system change was changed "to the amount of forest cover remaining, as the three major forest biomes-tropical, temperate and boreal-play a stronger role in land surface-climate coupling than other 
biomes.” Loss of biodiversity was renamed to change in biosphere integrity to reflect that the framework now emphasizes the impact of humans on ecosystem functioning. Simultaneously the original boundary was supplemented with a Biodiversity Intactness Index, which "assesses change in population abundance as a result of human impacts, such as land or resource use, across a wide range of taxa and functional groups at a biome or ecosystem level using pre-industrial era abundance as a reference point”. Finally, the updated framework included a boundary for atmospheric aerosol loading, which was not quantified in the original article. As the control variable aerosol optical depth (AOD) was adopted and taking a precautionary approach towards the uncertainty of its tipping point, a boundary at an AOD of 0.25 was proposed. (Steffen et al., 2015b)

All these changes to the planetary boundaries, and especially quantifying the boundary for atmospheric aerosol loading, since the original paper makes the chemical pollution boundary stand out. It has been renamed to the introduction of novel entities to reflect that humans can influence the Earth system through new technologies in many ways. In addition to pollution by toxic synthetic substances we need, for example, to be aware of the release of radioactive materials or nanomaterials. But novel entities still has no quantified boundary, in contrast to all the other planetary boundaries. Honestly, I do not even think it is possible to set a boundary value for novel entities in the planetary boundary framework. The simple reason is the enormous quantity of novel entities 
existing globally. Starting from the estimate used by Steffen et al. (2015b) that there are today more than 100000 substances in global commerce, we would potentially have to set 100000 separate planetary boundaries. And this is a very modest estimate, as this is the amount of different substances registered in the EU by 2001 (Commission of the European Communities, 2001).

As the new name suggest, each entity is novel, and creates thus also a novel risk. Each new novel entity that humankind invents, poses, until further knowledge, a risk to singlehanded cross a planetary boundary. Thus they cannot be summed up to a single measure in the way as for example $\mathrm{CO}_{2}$ equivalents in the case of climate change. Indeed, Rockström et al. (2009) noted in the original Planetary boundaries paper that: "It is impossible to measure all possible chemicals in the environment, which makes it very difficult to define a single planetary boundary derived from the aggregated effects of tens of thousands of chemicals.”

Lewis (2012: 417) argues that the boundaries concept has two important flaws. The first flaw "is that not all of the identified parameters are true thresholds that, once passed, can be recovered to move back to Holocene-like conditions,” but fixed limits. As an example he presents the disruption of the phosphorus cycle, which "is represented in the planetary boundaries concept as the quantity of phosphates flowing into the oceans from 
crop-fertilizer run-off... ...But more serious for humanity is that phosphorus is a key plant nutrient. Fertilizer is produced from rock phosphate, which forms on geological time scales. When it is gone, it is gone. This does not represent a threshold boundary: it is a depletion-limit. Humanity cannot use more rock phosphate than there is.”

The second weakness, according to Lewis (2012: 417; see also Brook et al.; 2013), relates to scale. "Some threshold boundaries are unambiguously global, such as climate change... Others, such as nitrogen pollution, are global only if local problems are widely replicated.” Lewis is worried that a global focus on all nine boundaries could spread the already weak political will thinly. As a solution he suggests that: "Global negotiations should focus on managing the clear global planetary boundaries of climate change and ocean acidification, as well as biodiversity loss, which has global drivers.” Acknowledging the difference between thresholds and fixed limits, is again in itself a solution to the first flaw.

Incidentally, Lewis (2012: 417) also mentions a third potential problem, that it would delude us to think that: "Here is humanity's safe space: within it, do what you want." The novel entities, as they now stands without quantified thresholds or fixed limits, are a good reminder that this is not the case; we have unleashed powers that are beyond our 
control, even to some degree beyond our full grasp. On good example is the story of chlorofluorocarbons (CFCs) and the ozone layer, which we will examine next.

\section{CFCs and the Ozone Layer}

Persson et al. (2013: 12620) suggest three conditions that "must be met simultaneously for a chemical or mixture of chemicals to pose a planetary boundary threat”:

1) The chemical or mixture of chemicals has a disruptive effect on a vital Earth System Process.

2) The disruptive effect is not discovered until it is, or inevitably will become, a problem on a planetary scale.

3) The effects of the pollutant in the environment cannot be readily reversed.

One such group of chemicals that tick all these boxes are chlorofluorocarbons (CFCs), which I will use as an example of the difficulty to set boundary values for novel entities. The question is how many chemicals or groups of chemicals we have out there, that ticks all three conditions. Let us, for arguments sake, assume that there is out there a chemical or group of chemicals with similar qualities as chlorofluorocarbons (CFCs). A normal screening process would consider them mostly harmless, as they are non-toxic, colourless, odourless, non-flammable and non-corrosive. 
Until 1974, when Molina and Rowland (1974) published their laboratory study on the photodissociation of chlorofluoromethanes in the stratosphere, CFCs were just a group of non-toxic, colourless, odourless, non-flammable and non-corrosive chemicals considered mostly harmless. This changed, as they showed that, the intense ultraviolet radiation in the of the upper atmosphere could, at least in theory, break the chemical bonds of CFCs, releasing free chlorine atoms, which reacts catalytically with ozone and results in its significant depletion. The US National Academy of Sciences (1976a, b) summed up the research so far in 1976, supporting Molina and Rowland's theory and the connection between ozone depletion and the increased incidence of skin cancer.

Measured evidence of ozone depletion was, however, not available until 1985, when the discovery of the annual depletion of ozone above the Antarctic was first announced (Farman et al., 1985). Sweden did not wait for this measured evidence, and announced in January 23, 1978 that it would ban aerosol sprays using CFCs as the propelling agent. The United States followed the example by the end of the year, and was joined by Canada, Norway, and Denmark within a few years (Andersen and Sarma, 2002; Byrd, 2015). The use of CFCs continued, however, in other applications, such as refrigeration and industrial cleaning. It would last until January 1, 1989 for the first global treaty on the protection of the ozone layer, the Montreal Protocol, to enter into force (Morrisette, 
1989). The discovery of the Antarctic ozone hole in 1985 provided the ultimate waking signal (Farman et al., 1985).

Following the conditions set out by Persson et al. (2013: 12620) "for a chemical or mixture of chemicals to pose a planetary boundary threat," CFCs would not be considered such if our knowledge of them would still be on the pre 1974 level. I doubt that the ozone layer would not be included as a planetary boundary, as no conceivable anthropogenic threat for it would be imagined. For example, Earth's magnetic field, the magnetosphere, which protects us from harmful radiation and hot plasma from the sun, is not included in the planetary boundaries, as no conceivable threats to it are currently considered. If not the ill-received 2003 movie The Core is considered as such.

CFCs would not even have been included in the original chemical pollution category, as they are not only non-toxic, but also colourless, odourless, non-flammable and noncorrosive. They were indeed originally developed as an non-toxic alternative as refrigerant to previously used toxic gases ammonia $\left(\mathrm{NH}_{3}\right)$, methyl chloride $\left(\mathrm{CH}_{3} \mathrm{Cl}\right)$, and sulphur dioxide $\left(\mathrm{SO}_{2}\right)$, after a series of fatal accidents in the 1920s, where methyl chloride leaked out of refrigerators (Elkins 1999). The original Limits to Growth -report from 1972, which the planetary boundaries framework builds upon, did not include references to Chlorofluorocarbons, freons or the ozone layer (Meadows et al., 1972). 
They would though be included in the as one of tens of thousands other novel entities in the updated planetary boundaries framework, showing the utility of amend the chemical pollution boundary into the novel entities boundary.

By the time of Molina and Rowland's first warning of potential dangers to the ozone layer caused by CFC's, they had been in commercial production for around forty years, since the 1930s (Okazoe, 2009). Fifteen years more were needed before the first global treaty, the Montreal Protocol, entered into force on January 1, 1989. This long delay and the manifold amount of human created novel entities compared to the 1930s, raises the question, how many novel entities we have nowadays in production that will in 40-50 years' time considered to threaten some vital planetary boundary. The novel entities, as such without a defined boundary value is a vital reminder of this problem.

\section{The Bad Anthropocene}

The alternative to the good Anthropocene is unfortunately not staying within the current stage of Great Acceleration, but moving into what I would call the bad Anthropocene. Lenton et al. (2008), for example, argue that in some regions anthropogenic forcing on the climate system could kick-start abrupt and potentially irreversible changes. They list nine policy relevant global sub-systems, which could pass such critical thresholds 
within the next hundred years. Of these, the extent of the Arctic sea-ice is already decreasing, but its total loss would devastate Arctic ecosystems. The exact tipping point for the disintegration of the Greenland ice-sheet is unknown, but a local warming of more than three degrees Celsius could cause its collapse resulting in a two to seven meters rise of the sea-level.

Hansen et al. (2016) recently cautioned that if greenhouse gas emissions continue to grow, multi-meter sea-level rise would become practically unavoidable already within 50-150 years. This paper is, however, highly controversial. For example, Drijfhout et al. (2015) argue that while "[t]he analysis does not contain any process that is physically impossible (albeit sometimes unlikely)... ... the scenarios sketched in this paper could be interpreted as an extreme high-end scenario that describes the upper bound of what one might expect in the coming centuries to happen with our current climate if carbon emissions continue at present-day rate.” On the other hand, available evidence suggests that scientists generally, and particularly in the IPCC assessments, have been conservative in their projections of the impacts of climate change (Brysse et al., 2013; Rahmstorf et al., 2007) Furthermore, Hansen et al.'s (2016) scenario might less likely to realize than the IPCC consensus scenarios, but acting according to it would be less risky. In the words of Meyer (2015): "If we follow IPCC and they have underestimated 
risk, we find out too late to do anything about it. If we follow Hansen and he has overestimated risk, we find out in time and can relax a bit."

Steffen et al. (2015b: 737) warns that, “A continuing trajectory away from the Holocene could lead, with an uncomfortably high probability, to a very different state of the Earth System, one that is likely to be much less hospitable to the development of human societies”. This bumpy road to a new stable state, that continued inaction would lead to, could well be named bad Anthropocene, but it is up to discussion whether this new stable state could still be considered the Anthropocene. The natural powers that overarching the tipping point will trigger are unleashed by human actions, but these powers themselves will not be in human control. Thus we would end up asking, how much human agency does the concept of Anthropocene requires? Future generations doomed by inaction to live in less hospitable circumstances would though have much more pressing issues at hand than discussing the name of this new state.

\section{Reclaiming the Anthropocene}

Hamilton (2015) and Hamilton and Grinevald (2015) fear that the early Anthropocene hypothesis and the good Anthropocene reframing may be counted as deflationary moves of the Anthropocene concept. If so, the reframing suggested above, could be counted as 
an even worse deflationary move. I argue, however, for the opposite as the suggested reframing of the good Anthropocene, with its strict prerequisites, would reclaim the Anthropocene concept from the techno-industrial hubris version set out in An Ecomodernist Manifesto (Asafu-Adjaye et al., 2015). It would put humans back in their rightful place on earth, not as gods as in the ecomodernist vision, but as one of many species although with large power for the good or the bad, and the responsibilities this brings along towards fellow humans and the non-human world. The Anthropocene would not become "good” by simply declaring it good, but by a fundamental change in our behaviour and attitudes, and in the resulting changes in the trajectory of human induced changes in the Earth System.

The reframing suggested in this paper, would furthermore give a more multifaceted picture of human agency in the Anthropocene, where humans as active creators of their own surroundings can be a force of both good and bad. The goldilocks climate of the Holocene, or at least its continuation, is to some degree due to human agency, while anthropogenic emissions of greenhouse gases are currently putting the Earth on a trajectory that might plunge us out of this stable climate. Thus it cannot either be used as an excuse for not dealing with and taking responsibility for the uneven distribution of responsibility for climate change and vulnerability for its consequences (Malm and Hornborg, 2014). I will not discuss these aspects further in this paper, as there are 
plenty of suggestions on how to deal with them (Matthews, 2016; Kunnas, 2013; Kunnas et al., 2014). I will though later in this article show how the good Anthropocene is a necessary condition for achieving United Nations Sustainable Development Goals.

This dualistic view on human agency would also fit better with our current knowledge that even World Heritage sites, like the Amazon in the south or Laponia in the north, considered by many as pristine wilderness, are to a large degree the outcome of human activities. According to Clement et al. (2015: 1) “The current consensus among historical ecologists suggests that Amazonia is a complex mosaic of coupled humannatural systems, typical of anthropogenic biomes or anthromes globally...” These human activities has also left clear markers in the soil stratigraphy, small patches of highly fertile soils which are known as Anthropogenic Dark Earths or terra preta de Índio (Glaser and Stoknes, 2014). Archaeological evidence and radiocarbon dating shows that they were formed by pre-Columbian inhabitants. Indeed, archaeologist Roosevelt (2013) suggests terra preta as a distinctive, although regional, marker of the Anthropocene. Only vague estimations about their total extension exist, but they might rang up to $10 \%$ of Amazonia (Mann, 2002). Similarly for Laponia in Sweden, Green (2009) notes that reindeer herding carried over thousands of years has shaped the natural landscape that formed the basis for the natural criteria of its appointment as World Heritage. 
Regarding Australia, there is a growing recognition that prior to British colonization, sophisticated land management practices of Indigenous people over millennia, such as controlled seasonal burning, ensured that the landscape appeared more alike a carefully managed park than an unpeopled wilderness (Instone and Taylor, 2015; Gammage, 2011). Again it is easy to find a similar example from the north. In Finland, for example, centuries of burning cultivation and following grazing has created environments that are nowadays officially classified as valuable landscapes from both cultural and environmental perspective (Kunnas, 2005; Maisema-aluetyöryhmä, 1993; Rassi et al., 2010). Similarly, it has been suggested that the Amazonian Dark Earths could act as a model for sustainable agriculture in the humid tropics (Glaser, 2007; Glaser and Stoknes, 2014).

\section{The true significance of the Anthropocene}

Bai et al. (2016, 351) argue that: "While the concept of the Anthropocene reflects the past and present nature, scale and magnitude of human impacts on the Earth System, its true significance lies in how it can be used to guide attitudes, choices, policies and actions that influence the future.” Furthermore, they argue: “...that it is time for debates 
on the sustainability of the Anthropocene to focus on opportunities for realizing desirable and plausible futures.” Next, I will show that the reframing suggested in this paper would provide a clear improvement in this sense.

Due to the newness of the Anthropocene concept, there does not seem to be much research about the best way to communicate it. In one of the few, I have seen, Comstock and Hocks $(2016,174)$ suggests as an alternative response to the current gloomy debate about the Anthropocene: "a critical sonic rhetoric that upsets dreams of human supremacy or even annihilation and celebrates contingency, enveloping humans in a complex soundscape of relations, birth, and decay.”

On the other hand, there is available a large amount of literature about climate change communication, which act as a more or less perfect substitute as climate change is one of the major drivers taking us from the Holocene to the Anthropocene. According to O'Neill and Nicholson-Cole (2009) strong representations of disaster and catastrophe can attract people's attention to climate change, but fear is generally an ineffective tool for motivating genuine personal engagement. Stoknes (2014) argues that such framing might even be counterproductive. An explanation for such counterproductive outcome is put forward by Foust and O'Shannon $(2009,161)$ who argues that "apocalyptic framing diminishes the range of human agency possible in influencing the inevitable 
march of global warming”. Analogously, it could be argued that especially the great acceleration framing of the Anthropocene might diminish the feeling of possibility to influence the inevitable march of the Anthropocene. In the words of Howell $(2011,3)$ : "People need to believe that they can do something about the problem, and that it is worth doing something."

Ojala (2012) argues that it is especially important to include young people in societal deliberations of climate change as they are those most likely to suffer from the negative consequences of climate change, and since they are the future leaders of society. Furthermore, she argues that: “Although many young people think climate change is an important societal issue, studies indicate that pessimism is quite common. Finding ways to instill hope could therefore be seen as vital.” (p. 625) The same could be argued to apply to the Anthropocene in general as well without modifications.

Stoknes (2014) lists five strategies and solutions for climate communication that engage positive emotion and behavior:

1. Story: Use the power of storytelling.

2. Supportive: Find deep framings that are positive and support action.

3. Signals: Use indicators and metrics that monitor progress on green growth and jobs.

4. Social: Use the power of social networks.

5. Simple: Make it easy and convenient to act in a climate-friendly manner. 
I suggest that the reframing of the Anthropocene as suggested in this paper would fulfil at least three of these five strategies and solutions:

It uses the power of storytelling by presenting a multifaceted picture of human agency in the Anthropocene, where humans as active creators of their own surroundings can be a force of both good and bad. For that it uses the concepts of good and bad Anthropocene.

The iconic symbols of the Anthropocene, the Great Acceleration graphs with their steep upward trends since the 1950s, attract people's attention to climate change and other human induced changes to the Earth system. To motivate genuine personal engagement these need to be counterbalanced with a message on the possibilities to turn these trends, which is provided by the suggested reframing of the good Anthropocene. Thus we have a deep framing that is positive and support action. $^{2}$

For signals regarding the movement towards the good or the bad Anthropocene either the Great Acceleration graphs or the Planetary Boundaries could be used. Based on the discussion above, I would suggest that the Planetary Boundaries are

\footnotetext{
${ }^{2}$ Deep framing refers to the connections between a particular communication strategy and a set of deeper values or principles (Lakoff, 2004).
} 
more suitable. First, they are only nine compared to the 24 Great Acceleration graphs, thus fitting better to the requirement of simplicity. It is, however, not possible to simplify the metrics into one like carbon dioxide equivalent in the case of climate change, as that is just one of many faces of the Anthropocene. Compared to all upward trending Great Acceleration graphs, the Planetary Boundaries also provide some degree of hope as only some of the Boundaries are transgressed so far. Furthermore, the Planetary Boundaries are recorded as key indicators of longterm planetary habitability for humans, something which importance should be clear to us all (Zalasiewicz et al., 2017).

The Great Acceleration graphs can still provide the necessary wake up call, while the Planetary Boundaries provides us the goals to move towards. According to Steffen et al. (2007) we would be at the beginning of the third stage of the Anthropocene, when the recognition that human activities are affecting the structure and functioning of the Earth System as a whole is filtering through to decision-making at many levels. I would say that this is too early point for calling it the good Anthropocene, but we could perhaps be called Stewards of the Earth System at that point.

Setting staying or moving within the Planetary Boundaries as the goal would also provide a clear link to the 17 Sustainable Development Goals (SDGs) of the United 
Nations, as they use goal-setting as a key strategy for global governance (Biermanna et al., 2017). Furthermore, staying within the Planetary Boundaries is a necessary condition for achieving the SDGs in the long run (Griggs, 2013). For example, climate change is both one of the Planetary Boundaries and one the SDGs, while it is established, that climate change, through increased extreme conditions, will worsen food security in Africa, hindering the goal to achieve zero hunger and food security (IPCC, 2014). It can also work the other way, as Kunnas (2013) argue that a mutual debt cancellation — developed countries' carbon debts versus developing countries' conventional monetary debts—would pave way for a truly global carbon treaty, while releasing funds for vital investments in human capital and infrastructure, such as schooling, healthcare or clean water. Thus it would provide a truly integrated solution fit for the Anthropocene, where pushing climate change back within its planetary boundaries would also advance several SDGs.

\section{Discussion and Conclusions}

The focus of this paper has been on storytelling, joining the footsteps of Bonneuil (2015) arguing that "Stories matter for the Earth". I have examined, whether the Anthropocene concept, can be used as as "a broad metaphor to motivate holistic 
understandings of human impacts on the Earth System.” (Bowman 2015, 73; see also Chin et al., 2013).

I have shown how a multi-stage lower-ace Anthropocene suggested by Ruddiman (2013) and Glikson (2013) could solve the human-centeredness of the concept, and most importantly unleash the power of storytelling by presenting a multifaceted picture of human agency in the Anthropocene. Thus also evade fatalistic thinking that the trajectory of current industrial-consumer civilization might evoke (Barje, 2015; Crist, 2007; Meyer, 2006).

Compared to Glikson's (2013) three staged model, I have added a fourth stage of the Anthropocene and suggested somewhat different earlier stages. Thus my suggestion for a four staged Anthropocene is the following one:

1) The early Anthropocene, which began 5000-14 000 years ago with the domestication of animals or the beginning of large-scale agriculture.

2) The first acceleration phase of the Anthropocene beginning with large-scale burning of coal at the time of the Industrial Revolution.

3) The post-1950 Great Acceleration.

4) And finally the good or the bad Anthropocene depending on whether humans take decisive action in time that ensures us staying within the planetary boundaries providing a safe operating space for humanity. 
I argue that this reframing of the good and the bad Anthropocene would put humans back in their rightful place on earth, not as gods as in the ecomodernist vision, but as one of many species although with large power for the good or the bad, and the responsibilities this brings along towards fellow humans and the non-human world (Asafu-Adjaye et al., 2015; Kotze, 2014). It gives a more multifaceted picture of human agency in the Anthropocene, where humans as active creators of their own surroundings can be a force of both good and bad. The goldilocks climate of the Holocene or at least its continuation is to some degree due to human agency, while anthropogenic emissions of greenhouse gases are currently putting the Earth on a trajectory that might plunge us out of this stable climate.

In the end, whether or how the Anthropocene continues matters more than when it began. Historical and prehistorical records show that development can be fast once a tipping point is reached. Luckily there are also positive tipping points as the solving of earlier environmental problems, like the acid rain and the ongoing recovery of the ozone layer, shows (World Meteorological Organization, 2014). Both the good Anthropocene, as defined in this article and the bad Anthropocene might be just one tipping point away. Thus, I support Bai et al.'s (2016, 351) argument that "the true significance of the Anthropocene concept lies in how it can be used to guide attitudes, choices, policies and 
actions that influence the future”. I argue that the reframing suggested in this paper would provide a clear improvement in this sense as it engage positive emotion and behaviour. It uses the power of storytelling by presenting a multifaceted picture of human agency in the Anthropocene, where humans as active creators of their own surroundings can be a force of both good and bad. It provides a deep framing that is positive and support action, and provides clear signals regarding the movement towards the good or the bad Anthropocene. The good Anthropocene would also provide necessary conditions for reaching United Nations Sustainable Development Goals.

\section{Bibliography}

Andersen, S. O., Sarma, K. M. (2002) Protecting the Ozone Layer: The United Nations History. London: Earthscan.

Angus, Ian (2015) When Did the Anthropocene Begin...and Why Does It Matter? Monthly Review 67, no. 4. http://monthlyreview.org/2015/09/01/when-did-theAnthropocene-beginand-why-does-it-matter/ (accessed 20 September 2016). Asafu-Adjaye, John et al. (2015) An Ecomodernist Manifesto. http://www.ecomodernism.org/manifesto (accessed 15 February 2017). 
Bai, Xumemei et al. (2016) Plausible and desireable futures in the Anthropocene: A new research agenda. Global Environmental Change, Volume 39, 351-362. http://dx.doi.org/10.1016/j.gloenvcha.2015.09.017 Barnett, Jon and Adger, W. Neil (2003) Climate Dangers and Atoll Countries. Climatic Change 61, no. 3: 321-37. doi: 10.1023/b:clim.0000004559.08755.88

Biermanna, Frank, Kanieb, Norichika and Kima, Rakhyun E. (2017) Global governance by goal-setting: the novel approach of the UN Sustainable Development Goals. Current Opinion in Environmental Sustainability Volumes 26-27, 26-31. doi:

10.1016/j.cosust.2017.01.010

Bonneuil, C. (2015) The geological turn: narratives of the Anthropocene. In: C.

Hamilton, C. Bonneuil, \& F. Gemenne (Eds.), The Anthropcene and the Global Environmental Crisis (pp. 17-32). Abingdon, Oxon?; New York, NY: Routledge. Bowman, David MJS (2015) What is the relevance of pyrogeography to the Anthropocene? The Anthropocene Review, Vol. 2(1) 73-76.

Braje, Todd J. (2015) Earth Systems, Human Agency, and the Anthropocene: Planet Earth in the Human Age. Journal of Archaeological Research, Vol. 23, No. 4, pp. 369396. DOI 10.1007/s10814-015-9087-y

Brook, Barry W. et al. (2013) Does the terrestrial biosphere have planetary tipping points? Trends in Ecology \& Evolution, 28, 396-401. http://ecotope.org/people/ellis/papers/brook_2013.pdf 
Brysse, K., Oreskes, N., O’Reilly, J., \& Oppenheimer, M. (2013) Climate change prediction: Erring on the side of least drama? Global Environment Change, 23, 327337.

Byrd, D. (2015) This date in science: Sweden goes first to ban aerosol sprays, Jan 23, 2015. Available at: http://earthsky.org/earth/this-date-in-science-sweden-goes-first-toban-aerosol-sprays

Carpenter, S. R. \& Bennett, E. M. (2011) Reconsideration of the planetary boundary for phosphorus. Environmental Research. Letters Vol. 6, No. 1.

Carrington, Damian (2016) The Anthropocene epoch: scientists declare dawn of humaninfluenced age. Guardian 29.8.2016. Available at:

https://www.theguardian.com/environment/2016/aug/29/declare-Anthropocene-epochexperts-urge-geological-congress-human-impact-earth

Chakkrabarty, Dipesh (2009) The climate of history: Four theses. Critical Inquiry 35: 197-222. doi: 10.1086/596640

Chernilo, Daniel (2016) The question of the human in the Anthropocene debate. European Journal of Social Theory, 1-17, doi: 10.1177/1368431016651874

Chin A, Fu R, Harbor J et al. (2013) Anthropocene: Human interactions with earth systems. Anthropocene 1(0): 1-2. 
Clement, Charles R. et al. (2015) The domestication of Amazonia before European conquest. Proceedings of the Royal Society B 282: 20150813. doi:

10.1098/rspb.2015.0813

Colebrook, Claire (2016) What is the Anthropo-Political? In: Tom Cohen, Claire

Colebrook and J. Hillis Miller, Twilight of the Anthropocene Idols. London: Open Humanities Press, 81-125. Available at:

http://openhumanitiespress.org/books/download/Cohen-Colebrook-

Miller_2016_Twilight-of-the-Anthropocene-Idols.pdf

Commission of the European Communities (2001) White paper: strategy for future chemicals policy. (COM2001 88 final). Brussels: Commission of the European Communities.

Comstock, Michelle and Hocks, Mary E. (2016) The Sounds of Climate Change: Sonic Rhetoric in the Anthropocene, the Age of Human Impact. Rhetoric Review, 35:2, 165175. doi: 10.1080/07350198.2016.1142854

Crist, Eileen (2007) Beyond the climate crisis: A critique of climate change discourse. Telos 141: 29-55

Crist, Eileen (2013) On the poverty of our nomenclature. Environmental Humanities 3: $129-147$.

Crist, Eileen (2015) The Reaches of Freedom: A Response to An Ecomodernist Manifesto,” Environmental Humanities, vol. 7, 2015, pp. 245-254. 
Crutzen, Paul (2002) Geology of Mankind. Nature 415, no. 6867: 23.

doi:10.1038/415023a

Crutzen, Paul and Eugene Stoermer (2000) The Anthropocene. Global Change Newsletter 41: 17.

Dalby, Simon (2016) Framing the Anthropocene: The good, the bad and the ugly. The Anthropocene Review 3, Issue 1, 33-51. doi:10.1177/2053019615618681

De Vries, W., J. Kros, C. Kroeze, S. P. Seitzinger. (2013) Asessing planetary and regional nitrogen boundaries related to food security and adverse environmental impacts. Current Opinion in Environmental Sustainability 5, 392-402.

doi:10.1016/j.cosust.2013.07.004

Drijfhout, S., Helsen, M., Haarsma, R., van de Wal, R., Williams, J. E., van den Hurk, B. (2015) Comment on: Ice melt, sea level rise and superstorms: evidence from paleoclimate data, climate modeling, and modern observations that global warming is highly dangerous. Atmos. Chem. Phys. Discuss. http://www.atmos-chem-physdiscuss.net/15/C6867/2015/acpd-15-C6867-2015-supplement.pdf Elkins, J. W. (1999) Chlorofluorocarbons (CFCs). In: Chapman \& Hall Encyclopedia of Environmental Science, ed. D. E. Alexander, and R. W. Fairbridge, 78-80. Boston, MA: Kluwer Academic. 
EPA (2014) New Chemicals - Basic Info. Available at:

http://www.epa.gov/opptintr/newchems/pubs/basicinfo.htm

EPA (2015) Learn About the Safer Choice Label. Available at:

http://www2.epa.gov/saferchoice/learn-about-safer-choice-label

Farman, J. C., B. G. Gardiner, and J. D. Shanklin. (1985) Large losses of total ozone in Antarctica reveal seasonal ClOx/NOx interaction. Nature 315(6016):207.

doi:10.1038/315207a0

Foust, Christina R. and O'Shannon, William (2009) Revealing and Reframing

Apocalyptic Tragedy in Global Warming Discourse. Environmental Communication 3, no. 2: 151-167, doi: 10.1080/17524030902916624.

Gammage, Bill (2011) The Biggest Estate on Earth: How Aborigines Made Australia, Sydney: Allen and Unwin.

Glaser, Bruno (2007) Prehistorically modified soils of Central Amazonia: a model for sustainable agriculture in the 21st century? Philosophical Transactions of the Royal Society B: Biological Sciences, 362 (B): 187-196 doi: 10.1098/rstb.2006.1978

Glaser, Bruno and Stoknes, Per Espen (2014) Carbon Capture and Use as an Alternative to Carbon Capture and Storage. In: Noureddine Benkeblia (ed.) Agroecology, Ecosystems, and Sustainability, CRC Press, 57-80. DOI: 10.1201/b17775-4 
Glikson, Andrew (2013) Fire and human evolution: The deep-time blueprints of the Anthropocene. Anthropocene, Vol. 3, pp. 89-92.

Green, Carina (2009) Managing Laponia, A World Heritage as arena for Sami ethnopolitics in Sweden, Acta Universitatis Upsaliensis. Uppsala Studies in Cultural Anthropology 47. Uppsala, 2009.

Griggs, David et al. (2013) Policy: Sustainable development goals for people and planet. Nature 495, 305-307. doi: 10.1038/495305a

Hamilton, Clive and Jacques Grinevald (2015) Was the Anthropocene anticipated? The Anthropocene Review 2, vol. 1: 59-72. doi: 10.1177/2053019614567155

Hamilton, Clive (2015) The Theodicy of the "Good Anthropocene. Environmental Humanities 7: 233-238.

Hansen, James et al. (2008) Target Atmospheric CO2: Where Should Humanity Aim? Open Atmospheric Science Journal, vol. 2, pp. 217-231. arXiv:0804.1126v3 Hansen, James et al. (2016) Ice melt, sea level rise and superstorms: Evidence from paleoclimate data, climate modeling, and modern observations that $2{ }^{\circ} \mathrm{C}$ global warming could be dangerous. Atmos. Chem. Phys., 16 (2016): 3761-3812 doi:10.5194/acp-16$3761-2016$ 
Howell, Rachel A. (2011) Lights, camera ... action? Altered attitudes and behaviour in response to the climate change film The Age of Stupid. Global Environmental Change 21, no. 1: 177-187. doi:10.1016/j.gloenvcha.2010.09.004 Instone, Lesley and Affrica Taylor (2015) Thinking about Inheritance Through the Figure of the Anthropocene, From the Antipodes and in the Presence of Others. Environmental Humanities 7: 133-150. doi: 10.1215/22011919-3616371

IPCC (2014) Summary for policymakers. In Climate Change 2014: Impacts, Adaptation, and Vulnerability. Cambridge: Cambridge University Press, pp. 1-32. Kotze, Louis J. (2014) Human rights and the environment in the Anthropocene. The Anthropocene Review 1 no. 3: 252-275. doi: 10.1177/2053019614547741 Kunnas, Jan (2005) A Dense and Sickly Mist From Thousands of Bog Fires: An Attempt to Compare the Energy Consumption in Slash-and-Burn Cultivation and Burning Cultivation of Peatlands in Finland in 1820-1920. Environment and History, Vol. 11 No. 4, 431-446. http://www.jstor.org/stable/20723553

Kunnas, Jan (2012) The Theory of Justice in a Warming Climate - John Rawls' theory applied to Finland. Electronic Green Journal, 1(34), 2012. http://bit.ly/1tcqWeN (16 pages) 
Kunnas, Jan (2013) An outline for funding adaptation and disaster management schemes. In: Climate Change and Disaster Risk Management, ed. by Walter Leal Filho, Berlin, Heidelberg: Springer-Verlag, 427-436. doi: 10.1007/978-3-642-31110-9_28 Kunnas, Jan et al. (2014) Counting Carbon: Historic emissions from fossil fuels, longrun measures of sustainable development and carbon debt. Scandinavian Economic History Review, Vol. 62, No. 3, 243-265.

Lakoff, G. (2004) Don't think of an elephant! Know your values and frame the debate. Vermont: Chelsea Green Publishing.

Latour, Bruno (2014) Agency at the time of the Anthropocene. New Literary History 45: 1-18. doi: 10.1353/nlh.2014.0003

Lenton, Timothy et al. (2008) Tipping elements in the Earth's climate system. PNAS 105, vol. 6: 1786-1793. doi: 10.1073/pnas.0705414105

Lewis, S. L. (2012) We must set planetary boundaries wisely. Nature News, 485(7399), 417. https://doi.org/10.1038/485417a

Mann, Charles C. (2002) The Real Dirt on Rainforest Fertility. Science: Vol. 297, Issue 5583, 920-923. doi: 10.1126/science.297.5583.920 (Accessed 19 September 2016).

Maisema-aluetyöryhmä (1993) Maisema-aluetyöryhmän mietintö osa I, Mietintö 66/1992, Helsinki: Ympäristöministeriö, Ympäristönsuojeluosasto. 
Malm, Andreas and Hornborg, Alf (2014) The geology of mankind? A critique of the Anthropocene narrative. The Anthropocene Review, Vol. 1(1) 62-69.

Matthews, H. Damon (2016) Quantifying historical carbon and climate debts among nations. Nature Climate Change 6, 60-64 doi:10.1038/nclimate2774

Meadows, D. H., D. L. Meadows, J. Randers, and W. W. Behrens. (1972) The Limits to Growth. New York: Universe Books.

Meyer, A. (2015) Interactive comment on "Ice melt, sea level rise and superstorms: evidence from paleoclimate data, climate modeling, and modern observations that $2{ }^{\circ} \mathrm{C}$ global warming is highly dangerous” by J. Hansen et al. Atmos. Chem. Phys. Discuss., 15, C5426-C5427.

Meyer, Stephen M. (2006) The End of the Wild. Cambridge, MA: MIT Press, 2006. Molina, M. J. and Rowland, F. S. (1974) Stratospheric sink for chlorofluoromethanes: chlorine atom-catalysed destruction of ozone. Nature 249, 810 - 812. doi:10.1038/249810a0

Morrisette, P. M. (1989) The evolution of policy responses to stratospheric ozone depletion. Natural Resources Journal 29: 793-820.

National Academy of Sciences. (1976a) Halocarbons, Effects on Stratospheric Ozone. Washington, D. C.: National Academy of Sciences. National Academy of Sciences. (1976b) Halocarbons, Environmental Effects of Chlorofluoromethane Release. Washington, D. C.: National Academy of Sciences. 
Ojala, Maria (2012) Hope and climate change: the importance of hope for environmental engagement among young people. Environmental Education Research 18, no. 5 (2012): 625-642. doi/abs/10.1080/13504622.2011.637157

Okazoe, T. (2009) Overview on the history of organofluorine chemistry from the viewpoint of material industry. Proceedings of the Japan Academy. Series B, Physical and Biological Sciences 85(8), 276-289. doi:10.2183/pjab.85.276

O'Neill, Saffron and Nicholson-Cole, Sophie (2009) Fear Won't Do It”: Promoting Positive Engagement With Climate Change Through Visual and Iconic Representations. Science Communication 30, no. 3: 355-379. doi: 10.1177/1075547008329201

Paglia, Eric (2015) Not a proper crisis. The Anthropocene Review 2, no. 3: 247-261. doi: $10.1177 / 2053019615604867$

Persson, L. M. et al (2013) Confronting Unknown Planetary Boundary Threats from Chemical Pollution. Environmental Science \& Technology 47, 12619-12622. doi: 10.1021/es402501c

Rahmstorf, S., A. Cazenave, J.A. Church, J.E. Hansen, R.F. Keeling, D.E. Parker, and R.C.J. Somerville (2007) Recent climate observations compared to projections. Science, 316, 709, doi:10.1126/science.1136843.

Rassi, Pertti, Hyvärinen, Esko, Juslén Aino and Mannerkoski, Ilpo eds. (2010) Suomen lajien uhanalaisuus - Punainen kirja 2010. Helsinki: Ympäristöministeriö ja Suomen ympäristökeskus. 
Rawls, John. (1999) A Theory of Justice (revised edition). Oxford: Oxford University Press.

Rockström, Johan et al. (2009) Planetary boundaries: Exploring the safe operating space for humanity. Ecology and Society 14, vol. 2.: 32.

http://www.ecologyandsociety.org/vol14/iss2/art32/

Roosevelt, A. C. (2013) The Amazon and the Anthropocene: 13,000 years of human influence in a tropic rainforest. Anthropocene 4: 69-87.

Ruddiman, William F., et al., (2015) Defining the epoch we live in. Science, 348: 38-39. DOI: 10.1126/science.aaa7297

Ruddiman, William (2013) The Anthropocene. Annual Review of Earth and Planetary Sciences 41: 45-68.

Ruddiman, William (2005) Plows, Plagues \& Petroleum - How Humans Took Control of Climate. Princeton and Oxford: Princeton University Press.

Ruddiman, William. (2003) The Anthropogenic Greenhouse Era Began Thousands of Years Ago. Climatic Change 61: 261-93.

Steffen, Will, Crutzen, Paul J.and McNeill, John R. (2007) The Anthropocene: Are Humans Now Overwhelming the Great Forces of Nature? Ambio 36, No. 8: 614-622. 
Steffen, Will, Broadgate, Wendy, Deutsch, Lisa, Gaffney, Owen and Ludwig, Cornelia (2015a) The trajectory of the Anthropocene: The Great Acceleration. The Anthropocene Review 2, vol. 1: 81-98. doi: 10.1177/2053019614564785

Steffen, Will, K. Richardson, J. Rockström, S. E. Cornell, I. Fetzer, E. M. Bennett, R. Biggs, S. R. Carpenter et al. (2015b) Planetary boundaries: Guiding human development on a changing planet. Science Vol. 347, Issue 6223, doi:10.1126/science.1259855 (Accessed 19 September 2016).

Stoknes, Per Espen (2014) Rethinking climate communications and the ”psychological climate paradox”. Energy Research and Social Science, 1: 161-170.

doi:10.1016/j.erss.2014.03.007

Taylor, Affrica and Pacini-Ketchabaw, Veronica (2015) Learning with children, ants, and worms in the Anthropocene: towards a common world pedagogy of multispecies vulnerability. Pedagogy, Culture \& Society 23, No. 4 (2015): 507-529. doi:10.1080/14681366.2015.1039050

Thomas, William Leroy. ed. (1956). Man's Role in Changing the Face of the Earth. Chicago, Ill.: University of Chicago Press.

Waters, Colin N. et al. (2016) The Anthropocene is functionally and stratigraphically distinct from the Holocene. Science 351(6269): aad2622. doi:10.1126/science.aad2622. 
Williams, Mark, Zalasiewicz, Jan, Haff, PK, Schwägerl, Christian, Barnosky, Anthony D, and Ellis, Erle C. (2015) The Anthropocene biosphere. The Anthropocene Review 2, no. 3. 196-219. doi: 10.1177/2053019615591020 (accessed 19 September 2016).

Working Group on the 'Anthropocene' (2016) Media note: Anthropocene Working Group (AWG), Posted at Aug 29, 2016. http://www2.le.ac.uk/offices/press/pressreleases/2016/august/media-note-Anthropocene-working-group-awg (Accessed 19.9.2016)

World Meteorological Organization (2014) Assessment for Decision-Makers: Scientific Assessment of Ozone Depletion, Report no. 56. Geneva: WMO, Global Ozone Research and Monitoring Project.

Zalasiewicz, Jan, Williams, Mark and Waters, Colin (2014) Can an Anthropocene Series be defined and recognized? Geological Society, London, Special Publications 395: 39-53. doi: 10.1144/SP395.16

Zalasiewicz, Jan, Steffen, Will, Leinfelder, Reinhold, Williams, Mark and Waters, Colin (2017) Petrifying Earth Process: The Stratigraphic Imprint of Key Earth System Parameters in the Anthropocene. Theory, Culture \& Society 34, Issue 2-3: 83-104. doi: $10.1177 / 0263276417690587$ 